\title{
Térszemlélet a doktori képzésben - Regionális tudományok a doktori képzésben
}

\section{Spatial approach in PhD schools - Regional sciences in PhD schools}

\author{
TÖRŐCSIK MÁRIA, SZONTÁGH KRISZTINA
}

\begin{abstract}
TÖRőcsIK Mária: egyetemi tanár, Pécsi Tudományegyetem, Gazdaságtudományi Intézet, Pécs; torocsik@ktk.pte.hu

SZONTÁGH Krisztina: PhD-hallgató, Pécsi Tudományegyetem, Regionális Politika és Gazdaságtan Doktori Iskola, Pécs; k.szontagh@gmail.com
\end{abstract}

Mária TÖRÖCSIK: professor, Institute of Business Administration, University of Pécs; torocsik@ktk.pte.hu Krisztina SZONTÁGH: PhD student, Doctoral School of Regional Policy and Economics, University of Pécs; k.szontagh@gmail.com

\section{A regionális tudományok tudományági sokszínüsége}

A térszemlélet egyre több tudományterület közelítésében jelenik meg. Krugman (1995) új irányzata szerint a közgazdaságtan azon célján túl, hogy megmagyarázza azt, hogy a gazdaság rendszere miként felel a »mit«, a »hogyan«, valamint a »ki számára« kérdéseire, megjelenik a »hol« kérdésköre is (Varga 2006, 7.). A tér fontosságának jeleként értelmezzük, hogy hazánkban viszonylag rövid idő elteltével intézményesültek a regionális tudományok, tudásbázisuk gazdagítására kutatóintézetek jöttek létre, folyóiratok jelentek meg, doktori iskolák programjaként is választhatóvá vált a diszciplína. A térhódítás különféle metszetekben vizsgálható, mi az intézményesülés egyik fontos megnyilvánulási formáját, a doktori iskolák létrejöttének folyamatát, a doktori iskolák közötti együttműködést elemezzük.

A regionális tudományoknak több tudományág is kiindulópontot adott, interdiszciplináris jellege a kezdetektől meghatározó. „A regionális ismeretek oktatásának kezdetei a gazdaságföldrajz keretében az ötvenes évekre (Markos György professzor) nyúlnak vissza. Önálló szakképzés formájában az MTA Regionális Kutatások Központja és a Janus Pannonius Tudományegyetem Közgazdaságtudományi Karának

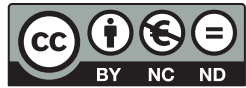


együttmüködésében egyetemi szinten, posztgraduális képzés keretében 1989-ben kezdödött el, és ezt követöen 1994-ben indult be a graduális, 1995-töl kezdve pedig a PhD képzés" (Buday-Sántha 2000, 165.).

A térkutatások közül a regionális tudományok tudományterületi és tudományági sokszínűséget mutatnak, egyszerre próbálnak elkülönülni a határtudományoktól és beépíteni azok eredményeit. „A regionális tudomány tárgya elkülönül az alkotó diszciplinák tárgyaitól, mivel abban a térbeliség, a területi jelleg lesz az egyedüli meghatározó" (Lengyel, Rechnitzer 2004, 19.). Az 1. ábra az idézett szerzőpáros illusztrációján alapul, tudományterületi és tudományági besorolás szerint részletezi a regionális tudományok alkotóelemeit (a tudományági és tudományterületi meghatározásoknál az Országos Doktori Tanács - http://www.doktori.hu - kategóriáit vettük alapul). Az ábra szerint a regionális tudományok eredményei több tudományterület és tudományág kombinatív együttgondolkodásának eredőjeként értelmezhetők. Nézzünk néhány példát arra, hogy milyen, a vizsgált tudományterületet és kapcsolódási pontjait jól magyarázó publikációk jelentek meg az elmúlt időszakban, fémjelezve a diszciplína főbb kérdéseit, beágyazódásának jeleit.

Lengyel Imre és Rechnitzer János 2004-ben rendszerezték a regionális gazdaságtan kialakulásában szerepet játszó tudományterületeket (Lengyel, Rechnitzer, 2004). A regionális tudományok módszertani magja szerintük a társadalomtudo-

1. ábra: A regionális tudományok tudományág sokszínűsége

The academic diversity of regional sciences as a discipline

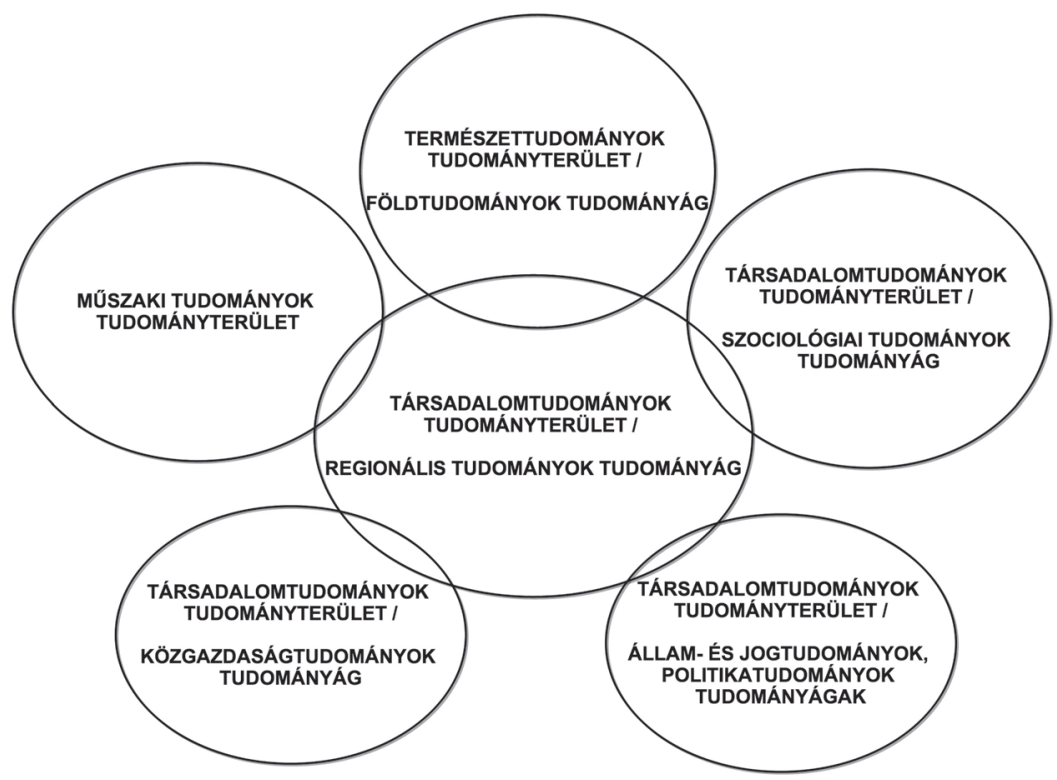

Forrás: Lengyel, Rechnitzer 2004, 21. alapján. 
mányokban eredeztethető, legfontosabb jellemzője az, hogy a térben zajló folyamatokat komplexen igyekszik kezelni. 2006-ban a regionális tudományok helyzetét, létjogosultságát Mészáros Rezső (2006) Rechnitzer János (1996), Nemes Nagy József (1998) és Horváth Gyula (1999) meghatározó tanulmányai alapján összegezte. 2008-ban megjelent Illés Iván Regionális gazdaságtan - területfejlesztés címü könyve, amely a Budapesti Műszaki és Gazdaságtudományi Egyetem hallgatói számára tankönyvként szolgálva mutatta be a regionális gazdaságtan körébe tartozó fogalmakat és folyamatokat, a címből adódóan a területfejlesztést helyezte előtérbe (Illés 2008). 2009-ben Lengyel Imre és Rechnitzer János szerkesztésében megjelent a regionális tudomány két évtizedének összefoglalása (Lengyel, Rechnitzer 2009), amelyben a területi irányítás, az intézményrendszer vizsgálata kapott kiemelt szerepet. Lengyel Imre például a regionális versenyképességről írt, melyben többek között azt indokolta, hogy miért használják egyre gyakrabban a versenyképesség fogalomkörét. Megfogalmazta azonban azt a kritikát is, hogy nagyon hosszú időnek kellett eltelnie, mire az érdeklődés középpontjába került a „hol” kategóriája (Lengyel 2009).

Berényi Dénes egy tanulmányában felhívja a figyelmet a Nobel-díjas Rudolf E. Peierls interdiszciplináris szemléletére: „A legkiválóbb eredmények közül sokat éppen olyan emberek értek el, és fognak is elérni, akik áthágják a tudományágak konvencionális felosztását, és akik hajlandók használni egy adott tudományterületen azokat az ötleteket, fogalmakat és eszközöket, amelyek egy másikon fejlödtek ki" (Berényi 2011, 340.).

Magyarország térszerkezetének modernizálásában, a regionális versenyképesség fejlesztésében a regionális kutatásoknak kiemelkedő jelentőségük van, Lengyel Imre 2010-es vitaindító tanulmányában kifejtette, hogy a földrajzi tér és az új társadalmi tér integrált szemléletű kezelése vitathatatlan fontossággal bír (Lengyel 2010).

Megállapíthatjuk tehát, hogy a térszemlélet növekvő jelentőségű a valós világban elérhető eredményességben, ezt képviselik a regionális tudományok meghatározó szerzői. Nem tagadják ugyanakkor, hogy a tudományterületek gyökerei más tudományterületekből fejlődtek ki, ezek adják az interdiszciplináris megtermékenyítő hatást.

\section{Fejlődéstörténeti áttekintés a regionális tudományi doktori iskolákról}

A magyar doktori képzés 1992-ben indult, először a doktori programok ideiglenes, majd 1994-től végleges akkreditálásával. A doktori programok helyébe 2001 januárjától a doktori iskolák léptek, amelyeket a Magyar Felsőoktatási Akkreditációs Bizottság (MAB) előbb ideiglenesen, majd túlnyomó többségükben véglegesen akkreditált. A doktori képzésre vonatkozó, jelenleg érvényes jogsza- 
bályok közül kiemelendő a felsőoktatási törvény 81 . § 1 . és 4 . bekezdése, amelyek szerint a MAB jóváhagyja a doktori iskolák működését, és dönt arról, hogy az egyetem mely tudományterületen, azon belül mely tudományágban folytathat doktori képzést, ítélhet oda doktori fokozatot. Emellett a MAB legalább nyolcévenként hitelesíti az iskolák minőségét, és ha azt állapítja meg, hogy a képzés színvonala miatt a doktori iskola programjai nem felelnek meg a képzési célnak, dönt az iskola működésének felfüggesztéséről. A jogi környezet változásával párhuzamosan a MAB a doktori programok, majd a doktori iskolák pályázati előírásait és a pályázatok elbírálási szempontjait is közzétette, végül 2002. június 28-án lezárta a magyar doktori iskolák akkreditációját. A korábban már ideiglenes akkreditációt kapott, valamint az időközben új, előakkreditációt kért doktori iskolák pályázatainak pozitív elbírálása eredményeképpen 2002 szeptemberétől Magyarországon 145 doktori iskola működött (Róna-Tas 2003).

A doktori iskolák közül azokat választottuk ki, amelyek területi kutatásokat folytatnak (továbbiakban „térszemléletű doktori iskolák”), a szükítés során gondolatébresztő volt Czirfusz Márton (2012) tanulmánya is. A doktori iskolákat két lépésben válogattuk ki. Elsőként a doktori.hu adatbázisából kiválasztottuk a regionális tudományok tudományterülettel rendelkező doktori iskolákat. Második lépésként e doktori iskolák vezetőivel folytatott szakértői mélyinterjúk tapasztalatai alapján bevontunk a vizsgálati körbe néhány jelentős agrártudományi, földtudományi, gazdálkodástudományi és közgazdaság-tudományi doktori iskolát is. A kutatásban nem tértünk ki azokra a kutatási területekre, amelyek nem a doktori iskolákban folynak, valamint amelyek az adott régiót érintik, de mégis más régiókban folynak.

Az első feltétel alapján 2011-ben a 167 akkreditált doktori iskola közül kimondottan a regionális tudományokban 4 egyetem 4 doktori iskolája képviselteti magát. Regionális tudományok doktori iskolák Dél-Dunántúlon 1996-tól a Pécsi Tudományegyetemen a Regionális Politika és Gazdaságtan Doktori Iskola, Észak-Alföldön 2002-től a Debreceni Egyetemen a Kerpely Kálmán Doktori Iskola, Nyugat-Dunántúlon 2004-től a Széchenyi István Egyetemen a Regionális- és Gazdaságtudományi Doktori Iskola és Közép-Magyarországon 2010-től a gödöllői Szent István Egyetemen a Regionális Tudományok Doktori Iskola.

A doktori iskolák vezetőivel készített mélyinterjús kutatásból kiderült, hogy a regionális tudományokon kívül további doktori iskolák kutatási és együttmúködési tevékenységébe is beépült a térszemlélet. Ebbe a kategóriába tartozik Dél-Alföldön a Szegedi Tudományegyetemen a Közgazdaságtani Doktori Iskola, ahol a képzés 1999-ben kezdődött, Dél-Dunántúlon a Kaposvári Egyetemen 2002-től a Gazdálkodás- és Szervezéstudományok Doktori Iskola, a Pécsi Tudományegyetemen 1994-től a Földtudományok Doktori Iskola és az Interdiszciplináris Doktori Iskola, Észak-Magyarországon a Miskolci Egyetemen 1994-től a Vállalkozáselmélet és gyakorlat Doktori Iskola, Közép-Magyarországon a Budapesti Corvinus Egyetemen 2000-től a Gazdálkodástani Doktori Iskola és az Eötvös Loránd Tudományegyetemen 1994-től a Földtudományi Doktori Is- 
2. ábra: A térszemléletű doktori iskolák alapításának kronológiája The evolution of doctoral schools in regional sciences

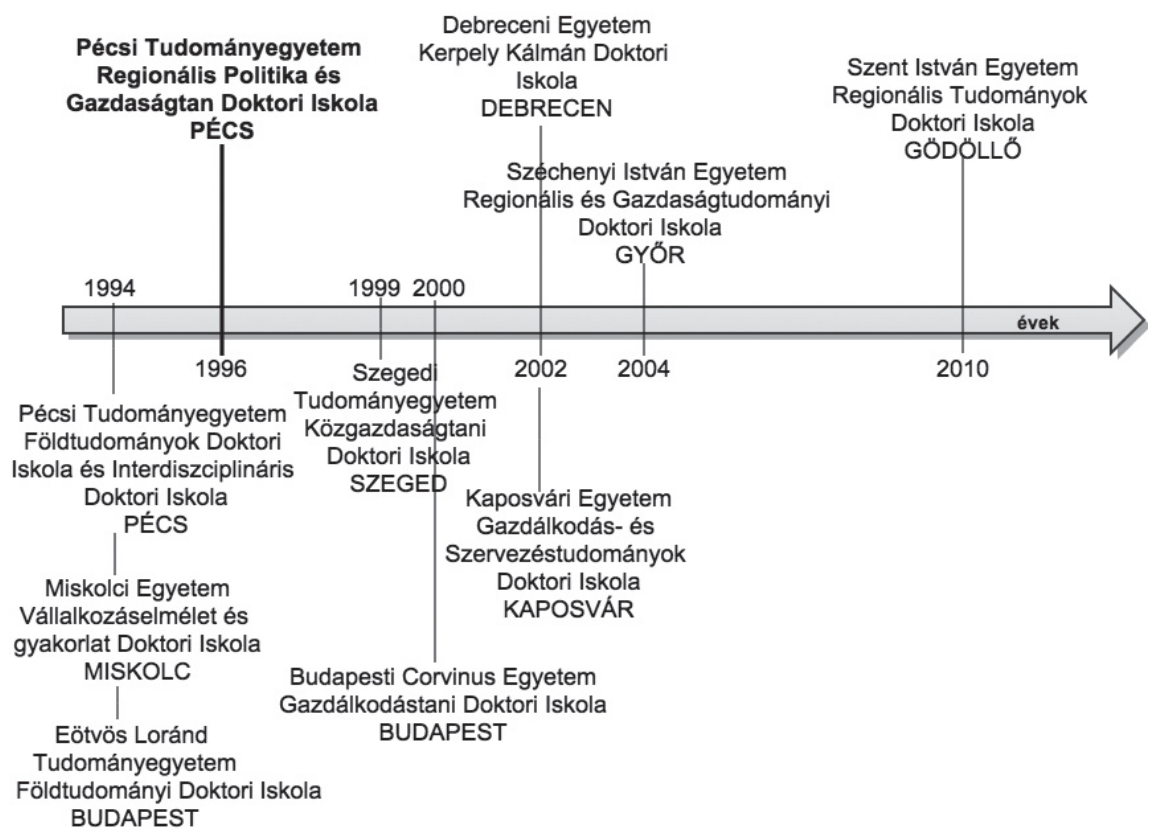

kola. A dátumok a képzés kezdetének évét jelzik a doktori.hu adatbázisa alapján. A kapott információk alapján a 2. ábrán a kutatási és együttmüködési tevékenységükben térszemléletet követő doktori iskolák fejlődéstörténetét vázoltuk fel.

A kezdeti szakaszban jellemzően földtudományi doktori iskolák láthatók, majd a specializáltabb, tisztán regionális tudományi doktori képzés úttörője, a Pécsi Tudományegyetem Regionális Politika és Gazdaságtan Doktori Iskola következik. A következő szakaszban fóként gazdálkodástani doktori iskolák jöttek létre, a sort hosszú szünetet követően a gödöllői Regionális Tudományok Doktori Iskola zárja.

\section{Térszemlélet a doktori iskolák kutatásaiban}

A vizsgált doktori iskolákban a regionális tudományok sokszínűsége az egyes doktori iskolák kutatási irányának egyediségében is megmutatkozik. Kutatásunk azt mutatta, hogy a doktori iskolák kulcsszereplőinek, vagyis vezető oktatóinak tevékenysége, tudományos szemlélete nagy hatást gyakorol az intézmény tudományos irányultságára. Jellemzően az iskolavezető által képviselt kutatási területek köré szerveződik a doktori iskola, ez határozza meg profilját és aktivitását. A doktori iskolák kutatásaira komoly hatást gyakorol még az 
1. táblázat: Területi kutatások a doktori iskolákban

Regional research in the doctoral schools

\begin{tabular}{|c|c|}
\hline Doktori & A területi kutatások megjelenése a doktori iskolában \\
\hline $\begin{array}{l}\text { Debreceni Egyetem, Kerpely } \\
\text { Kálmán Doktori Iskola } \\
\text { (társadalomtudományok, } \\
\text { regionális tudományok) } \\
\text { Dr. Rőfi Mónika, egyetemi tanár, az } \\
\text { Alumni Központ vezetője } \\
\end{array}$ & $\begin{array}{l}\text { Határon túli együttmúködések vizsgálata, a magyar-román } \\
\text { együttműködésekre koncentrálva, ukrán kapcsolódási } \\
\text { pontokkal kiegészítve. Az iskola kutatási irányultságát } \\
\text { befolyásolja a területi elhelyezkedéshez kapcsolódó történelmi } \\
\text { múlt is. }\end{array}$ \\
\hline $\begin{array}{l}\text { Eötvös Loránd Tudományegyetem, } \\
\text { Földtudományi Doktori Iskola } \\
\text { (természettudományok, } \\
\text { földtudományok) } \\
\text { Dr. Nemes Nagy József, egyetemi tanár, } \\
\text { a Regionális Tudományi Tanszék } \\
\text { vezetoóje }\end{array}$ & $\begin{array}{l}\text { A hallgatók egy része a regionális tudományok területén kutat, } \\
\text { másik része tisztán földrajzos témában folytatja kutatásait. Az } \\
\text { átalakult képzési folyamatban jelent meg az egyetemen az } \\
\text { általános terület- és településfejlesztés, valamint a regionális } \\
\text { tudományok, annak elméleti és módszertani kérdéseivel. A } \\
\text { doktori iskolába érkező hallgatók már a graduális képzés során } \\
\text { megismerhették a regionális tudományok alapjait. Az 1990-es } \\
\text { évek közepétől jelent meg az iskola kutatásaiban a területiség. }\end{array}$ \\
\hline $\begin{array}{l}\text { Kaposvári Egyetem, Gazdálkodás- } \\
\text { és Szervezéstudományok Doktori } \\
\text { Iskola (társadalomtudományok, } \\
\text { gazdálkodás- és } \\
\text { szervezéstudományok) } \\
\text { Dr. Udovecz Gábor, egyetemi tanár, a } \\
\text { doktori iskola vezetője }\end{array}$ & $\begin{array}{l}\text { Az iskola fő kutatási profilja nem a regionális tudományokra } \\
\text { épül, bár azokat szervesen áthatja. A hallgatók kutatják a } \\
\text { vállalkozások, a vállalkozókészség területi differenciáit, a } \\
\text { különböző európai projektek regionális hatásait. A doktori } \\
\text { iskola kutatási szemléletét és módszertanát a } \\
\text { marketingtudományok jelentősen áthatják, amely jelenség a } \\
\text { regionális kutatásokban hangsúlyos. }\end{array}$ \\
\hline $\begin{array}{l}\text { Miskolci Egyetem } \\
\text { Vállalkozáselmélet és gyakorlat } \\
\text { Doktori Iskola } \\
\text { (társadalomtudományok, } \\
\text { gazdálkodás- és } \\
\text { szervezéstudományok) } \\
\text { Dr. Szintay István, egyetemi tanár, a } \\
\text { doktori iskola vezetője } \\
\end{array}$ & $\begin{array}{l}\text { A regionális tudományok és vidékfejlesztés számos kutatás } \\
\text { alaptémáját jelenti. A tantárgyi összetételben is komoly } \\
\text { szerepet kapnak a regionális tudományok. A geográfus } \\
\text { szakemberek is hangsúlyosan foglalkoznak a regionális } \\
\text { tudományokkal. A turizmus gazdasági kérdéseiben gyakran } \\
\text { előtérbe kerülnek a regionális tudományok. }\end{array}$ \\
\hline $\begin{array}{l}\text { Pécsi Tudományegyetem } \\
\text { Regionális Politika és Gazdaságtan } \\
\text { Doktori Iskola } \\
\text { (társadalomtudományok, } \\
\text { regionális tudományok) } \\
\text { Dr. Buday-Sántha Attila, egyetemi } \\
\text { tanár, a doktori iskola korábbi vezetője } \\
\text { és } \\
\text { Dr. Varga Attila egyetemi tanár, a } \\
\text { doktori iskola jelenlegi vezetője }\end{array}$ & $\begin{array}{l}\text { A szakmai alapok letételében az MTA KRTK RKI (volt RKK) } \\
\text { szakemberei, kutatói jelentettek elengedhetetlen segítséget. A } \\
\text { környezet-gazdaságtanban például benne foglaltatnak az } \\
\text { agrártudományok, a vidékfejlesztés és a területfejlesztés } \\
\text { ismeretei. } \\
\text { Az iskola szoros kapcsolatban van az MTA KRTK RKI-vel (volt } \\
\text { RKK), és az ország különböző területeiről sok neves oktató, } \\
\text { kutató vesz részt a regionális tudományok doktori oktatásában. }\end{array}$ \\
\hline
\end{tabular}




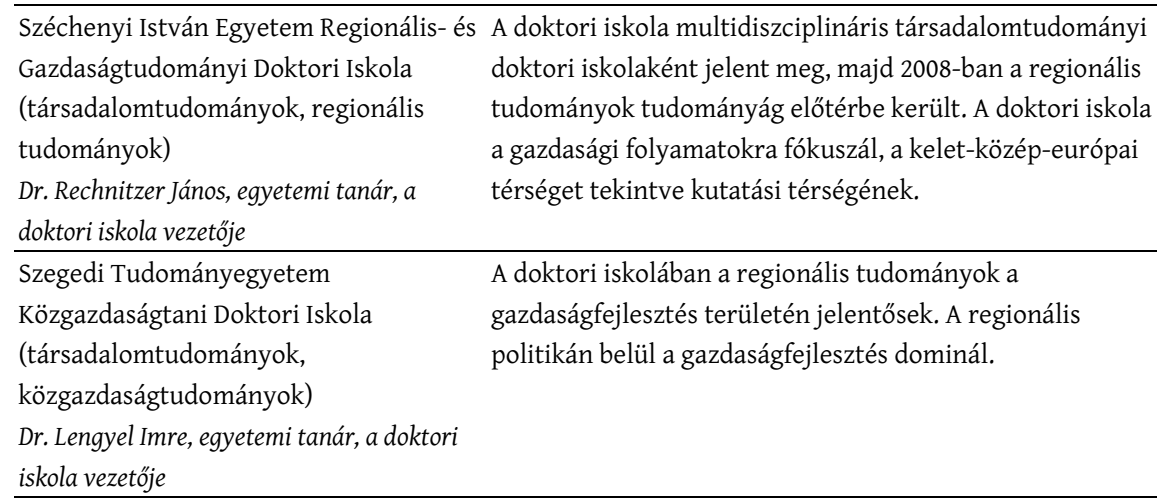

iskola elhelyezkedése, amelyet értelmezhetünk mind az adott gazdasági térben, mind a földrajzi térben, sőt az adott intézményi struktúrában is - az intézményi struktúrában való elhelyezkedésen az iskola egyetemi karhoz vagy tudományos centrumhoz való tartozása értendő. A térszemléletű doktori iskolák esetében kiemelkedő jelentőségü az MTA Regionális Kutatások Központjával (jelenleg: MTA KRTK Regionális Kutatások Intézete) kiépített kapcsolat, mert ez a térszemléletű kutatások tudományos nívójának megalapozását biztosíthatja a doktori iskolák számára. Az 1. táblázatban összefoglaltuk, hogy a nyolc szakértői mélyinterjú során az iskolavezetők szerint milyen értelemben jelenik meg a területiség, a regionalitás doktori iskolájuk kutatási témáiban. (Az interjúk a doktori iskolák vezetőivel, személyes felkereséssel történt; a beszélgetésekről hangfelvétel, majd jegyzőkönyv készült.)

A szakértői mélyinterjúk elkészítése során célunk az volt, hogy minden olyan (elsősorban társadalomtudományi) doktori iskola vezetőjéhez eljussunk, amely iskolában területi kutatásokat végeznek. A táblázatban a doktori iskolák neve mellett a doktori.hu adatbázisa alapján a tudományterületi és tudományági besorolás található. Kutatásunk szerint a területiség különféle tudományágakban jelenik meg a társadalomtudományok tudományterületen belül, de egyéb tudományterületek tudományágaiban is megfigyelhető térszemléletű kutatási irány. Ilyenek például a társadalomtudományokon belül a gazdálkodás- és szervezéstudományok, a közgazdaságtudományok, a politikatudományok és a regionális tudományok tudományágai. Kapcsolódó tudományterületek az agrártudományok és a természettudományokon belül a földtudományok tudományág.

A táblázaton és kutatási fókuszunkon ugyan túlmutat, de fontos rögzíteni, hogy a térszemlélet megjelenik még a társadalomtudományok tudományterületen belül a szociológiai tudományban, a természettudományok tudományterületen belül a matematika- és számítástudományok tudományágban, a müszaki tudományok tudományterületen belül az építő- és építészmérnöki tudományágakban, az informatikatudományok tudományágban, a katonai-műszaki tudományok tudományágban és a közlekedéstudományok tudományágban is. 
A doktori iskolák kutatási területeiben - a szakirodalmi kutatások térszemléletre vonatkozó megállapításai és az interjúk alapján - tudományterületi és tudományági összekapcsolódás egyaránt jellemző.

\section{Tudományos együttmüködések}

A doktori iskolák közötti tudományos együttműködések vizsgálatát két lépcsőben folytattuk le. Elsőként a doktori iskolák közötti tudományos együttmüködések jellegéről, annak szorosságáról kérdeztük meg a doktori iskolák vezetőit a szakértői mélyinterjúk során. Második lépésként a doktori.hu adatbázisa alapján megvizsgáltuk a törzstagok doktori iskolákhoz füződő tudományos együttműködésének irányait és típusait.

A vizsgálatok alapján a doktori iskolákban a személyi jellegű együttmüködések jellemzőbbek, mint az intézményi együttműködések. Egymás kölcsönös szakmai elismerése személyenként és intézményenként egyaránt példamutató. A doktori iskolák együttműködése személyes és a doktori iskolák közötti együttmüködéseken túl további intézményi kapcsolatokban is megvalósul. Meghatározó például a Magyar Tudományos Akadémia Regionális Tudományi Bizottsága, az MTA Közgazdaság- és Regionális Tudományi Kutatóközpont Regionális Kutatások Intézete, amelyek elnökei, tagjai, munkatársai többek között a felsorolt doktori iskolák munkájában is részt vesznek. Ezen kívül a doktori.hu adatai szerint a doktori iskolák törzstagjai saját egyetemükön több doktori iskolában is végeznek oktatói, témavezetői tevékenységet, de más egyetemek doktori iskoláival közös oktatásban, témavezetésben, témakiírásban csak ritkábban működnek együtt (főképp időhiány okán).

A doktori iskolák között a legintenzívebb tudományági együttműködés a Pécsi Tudományegyetem Regionális Politika és Gazdaságtan Doktori Iskola és a Széchenyi István Egyetem Regionális- és Gazdaságtudományi Doktori Iskola között figyelhető meg. Azt is vizsgálhatjuk, hogy a doktori iskolák törzstagjainak intézményi együttműködései összességében milyen mértékűek. Az adatok alapján a Pécsi Tudományegyetem Regionális Politika és Gazdaságtan Doktori Iskolája mutatja a legnagyobb együttműködési intenzitást, amelyet a Szegedi Tudományegyetem Közgazdaságtudományi Doktori Iskolája követ. Az intézmények közötti tudományos együttműködések intenzitását általában a doktori iskolák vezetőjének szemlélete és a doktori iskola pénzügyi háttere határozza meg.

A szakértők mindezen összekapcsolódások ellenére egyértelműen hiányolják a közös projektekben való együttműködéseket, amelyek mélyíthetnék az intézményi kapcsolatokat, megszüntethetnék a kapcsolatok esetlegességeit. 


\section{A hallgatók tudományos együttmüködései}

A kutatás során megvizsgáltuk a térszemléletű doktori iskolák PhD-hallgatóinak együttműködésekre vonatkozó véleményét is. Célunk az volt, hogy hallgatói fókuszcsoportos vitákat szervezve összegyüjtsük a véleményeket a hallgatói kapcsolatépítésről, együttműködésről. A 2. táblázatban összefoglaltuk, hogy az országban mely doktori iskolában hány hallgató részvételével szerveztünk fókuszcsoportos vitákat 2013-ban. Általában kisebb létszám volt jellemző, mert meglehetősen nehéz volt aktivizálni a hallgatókat, főképp úgy, hogy ebben kevés szervezési segítségre számíthattunk. Ennek ellenére a legfontosabb doktori iskolákból meghatározó véleményeket gyüjthettünk, amelyekből konklúziókat vonhattunk le.

A fókuszcsoportos viták szervezése során a hallgatói részvétel meglehetősen alacsony volt, ami több tényezőre is visszavezethető. A meghirdetett vitákra fóként nappali doktori képzésben résztvevő hallgatók jöttek el, bár a viták időpontját igyekeztünk úgy szervezni, hogy a levelező képzésben részt vevő hallgatók is képviseltethessék magukat (azokat a napokat jelöltük ki, amelyeken a hallgatók elvileg órát látogattak). Ennek ellenére nagyon kevés levelezős hallgató jött el a vitákra. A doktori képzések nagymértékủ lemorzsolódási arányára utalhat, hogy a nappalis hallgatók közül csak azok jöttek el, akik valóban aktívan dolgoznak a fokozatszerzésen, őket érdekelte a téma komolyabb mértékben. A viták kezdetén a hallgatók enyhén ellenségesek voltak, majd amikor egyértelművé vált számukra, hogy segítő szándékú kérdéseinkkel ténylegesen a doktori képzésről alkotott véleményüket szeretnénk megismerni, örültek a lehetőségnek, hogy meghallgatják őket.

2. táblázat: A hallgatói fókuszcsoportos megbeszélések létszámadatai Data about focus groups with PhD students

\begin{tabular}{lc}
\hline \multicolumn{1}{c}{ A fókuszcsoportos vita helyszíne, a doktori iskola neve } & A fókuszcsoport létszáma \\
\hline $\begin{array}{l}\text { Debrecen } \\
\text { Debreceni Egyetem, Kerpely Kálmán Doktori Iskola }\end{array}$ & 6 fö \\
\hline $\begin{array}{l}\text { Budapest } \\
\text { Eötvös Loránd Tudományegyetem, Földtudományi Doktori Iskola }\end{array}$ & 5 fö \\
\hline $\begin{array}{l}\text { Kaposvár } \\
\text { Kaposvári Egyetem, Gazdálkodás- és Szervezéstudományok Doktori Iskola }\end{array}$ & 7 fó \\
\hline $\begin{array}{l}\text { Miskolc } \\
\text { Miskolci Egyetem, Vállalkozáselmélet és gyakorlat Doktori Iskola }\end{array}$ & 5 fó \\
\hline $\begin{array}{l}\text { Pécs } \\
\text { Pécsi Tudományegyetem, Regionális Politika és Gazdaságtan Doktori Iskola }\end{array}$ & 9 fó \\
\hline $\begin{array}{l}\text { Győr } \\
\text { Széchenyi István Egyetem, Regionális- és Gazdaságtudományi Doktori Iskola }\end{array}$ & 4 fó \\
\hline $\begin{array}{l}\text { Szeged } \\
\text { Szegedi Tudományegyetem, Közgazdaságtani Doktori Iskola }\end{array}$ & 5 fó \\
\hline
\end{tabular}


Amikor a doktori iskolák hallgatóit a hallgatók közötti együttműködésekről kérdeztük, jellemzően problémákat és akadályozó tényezőket említettek. A hallgatók úgy tapasztalták, hogy egymástól elszigetelt módon kutatnak, nem tudnak egymás kutatásairól sem évfolyam-, sem országos szinten. A kutatási témán túl személyesen is kevéssé ismerik a többi hallgatót. A közös konferenciák és nyári táborok - ha vannak - ugyan árnyalják a képet, de a hallgatóknak jellemzően nincsenek kiépült kutatói kapcsolataik. Tapasztalati tőke szempontjából fontosnak tartanák a végzett hallgatókkal való kommunikációs csatornák kialakítását, erre viszont kialakult gyakorlatot nem tudtak említeni. A hallgatók praktikusnak tartanák, ha a tanórák - szervezés okán kialakult - „üresjárataiban" vagy legalább a kezdetekkor a doktori iskolák informális találkozási lehetőségeket kínálnának. Pozitív példa az Eötvös Loránd Tudományegyetem Földtudományi Doktori Iskola hallgatói összefogása. Itt a hallgatók klubot hoztak létre egymás munkájának elősegítésére; a bizalmi kapcsolat személyes ismeretségeken és rendszeres találkozáson alapul. Találkozóikon a hallgatók kutatási témáikat közösen véleményezik és hozzászólásokat, szakirodalmi ajánlásokat fogalmaznak meg egymás számára. Ezeken az alkalmakon kizárólag hallgatók jelennek meg, önszerveződő módon. Általánosságban megállapítható volt a beszélgetésekből, hogy a kutatási eredmények féltése csak kismértékben jelentkezik a hallgatók körében, ami ennek a tudományos generációnak akár óriási előnye is lehet, megkönnyítve körükben a munkamegosztás gyakorlatának létrejöttét.

A doktori iskolákban a helyi együttműködés jellemzően a tantárgyi követelmények és a fontosabb információk megosztásában nyilvánul meg, a hallgatók legfőbb kommunikációs csatornája jellemzően a közös levelezőlista. A helyi szintű együttműködések eredményeként a hallgatók esetenként a költségek megosztása érdekében együtt utaznak konferenciákra, de a társszerzős konferencia-előadások száma elenyésző. Nem jellemző a közös publikáció sem, főleg a témák szerteágazó volta miatt.

Jelenleg a hallgatók legfontosabb helyi szintű kapcsolatai a konzulens és a doktori iskola adminisztrátora. A hallgatók nehezményezik, hogy a helyi szintű kapcsolatok elmélyítésére nem kapnak konkrét segítséget, nincs ismeretük a helyi kutatási témákról, továbbá nem vagy csak nehezen tudnak kutatási projektekhez csatlakozni. A helyi együttműködésekre jellemző, hogy a nappalis hallgatók között kiterjedtebb a kommunikáció, mint a levelezős hallgatók között: a nappalis hallgatók személyes ismeretségei kiépültebbek a gyakoribb találkozási alkalmak miatt. Az országos szintű hallgatói kapcsolatok építésében jelenleg a legnagyobb közremüködő szervezet a Doktoranduszok Országos Szövetsége.

A hallgatók a tudományos együttműködéseket hallgatók közötti együttműködésként értelmezik, igénylik az együttműködések számának és formáinak növelését. Az együttműködések végső célja alapvetően a sikeres fokozatszerzés. A hallgatók jelenlegi legfontosabb együttműködési formái a vizsgafelkészülés során a kölcsönös segítségnyújtás, a publikálásban a konzulenssel való együtt- 
müködés, az információszerzésben pedig az informálódás a felsőbb évfolyamok hallgatóitól és a doktori iskolák adminisztrátoraitól. A fókuszcsoportos vitákon elhangzottak szerint a jelenlegi együttmüködési formák szük körünek bizonyulnak.

\section{Összegzés}

A doktori iskolák tudományos kutatásaiba egyre inkább beépül a területi szemléletmód. A tisztán térszemléletű doktori iskolák meghatározása nem egyszerü, hiszen a térszemlélet számos tudományterület tudományágát érinti. A doktori iskolák kutatási témái rendkívül összetettek, hiszen a doktori iskolák törzstagjainak tudományos háttere sokszínű. Ennek eredményeként a doktori iskolák által kínált kutatási témák palettája tudományterületi és tudományági besorolás szerint is interdiszciplináris, ami lehetőséget jelent az intézményeken belüli és az intézmények közötti tudományos kapcsolódási pontok megtalálására.

Tanulmányunkban a tudományos együttműködéseket vizsgáltuk intézményi és hallgatói megközelítésben. Az egyetemek számára rendelkezésre álló, szűkülő kutatás-fejlesztési források - ma már inkább K+F+I (Németh 2014) - miatt a kutatásfinanszírozásra hazai és nemzetközi pályázati források megtalálása, hazai és nemzetközi tudományos együttműködések szervezése szükséges a doktori iskolák számára. A szakértői mélyinterjúk és a hallgatói vélemények is azt tükrözik, hogy a tudományos együttműködések jelenlegi mértéke az elvártnál alacsonyabb. Az elvárt mérték egzaktan ugyan nem határozható meg, igények, javaslatok azonban elhangoztak a szakértői mélyinterjúk és a hallgatói fókuszcsoportos viták során is. Minden vizsgált szereplő a jelenleginél nagyobb gyakoriságú és intenzitású tudományos együttmüködéseket tartana célszerünek.

\section{Irodalom}

Berényi D. (2011): Határok nélküli tudomány. Magyar Tudomány, 3., 340-346.

Buday-Sántha A. (2000): A „Regionális felsőoktatás 2000” címü konferencia főbb megállapításai és javaslatai. Tér és Társadalom, 4., 165-166.

Czirfusz M. (2012): A térszemlélet szerepe a regionális tudomány, a gazdaságföldrajz és a közgazdaságtan viszonyában. In: Rechnitzer J., Rácz Sz. (szerk.): Dialógus a regionális tudományról. Széchenyi István Egyetem, Regionális- és Gazdaságtudományi Doktori Iskola, Magyar Regionális Tudományi Társaság, Győr, 52-59.

Horváth Gy. (1999): Kutatás, felsőoktatás és regionális átalakulás: Az innováció szerepe a regionális fejlődésben. Magyar Tudomány, 4., 447-458.

Illés I. (2008): Regionális gazdaságtan - Területfejlesztés. Typotex, Budapest

Krugman, P. (1995): Development, geography and economic theory. MIT Press, Cambridge

Lengyel I. (2009): A regionális versenyképességről. In: Lengyel I., Rechnitzer J. (szerk.): A regionális tudományok két évtizede Magyarországon. Akadémiai Kiadó, Budapest, 233-265. 
Lengyel I. (2010): A regionális tudomány „térnyerése”: reális esélyek avagy csalfa délibábok? Tér és Társadalom, 3., 11-40.

Lengyel I., Rechnitzer J. (2004): Regionális gazdaságtan. Dialóg Campus Kiadó, Budapest, Pécs

Lengyel I., Rechnitzer J. (szerk.) (2009): A regionális tudományok két évtizede Magyarországon. Akadémiai Kiadó, Budapest

Mészáros R. (2006): A társadalomföldrajz és a regionális tudomány Magyarországon. Magyar Tudomány, 1., 21-28.

Nemes Nagy J. (1998): A tér a társadalomkutatásban. Hilscher Rezső Szociálpolitikai Egyesület, Budapest

Németh T. (2014): Vezetői koncepció a Magyar Tudományos Akadémia elnöki feladatainak ellátására. Magyar Tudomány, 4., 486-493.

Rechnitzer J. (1996): A regionális folyamatok sajátosságai és jövőbeli fejlődési irányai. Magyar Tudomány, 11., 1347-1360.

Róna-Tas A. (2003): A magyar doktori iskolák helyzete és jövője. Magyar Tudomány, 10., 1298-1307.

Varga A. (2006): Térszerkezet, technológiai fejlődés és makrogazdasági növekedés. PTE Közgazdaságtudományi Kar, Pécs

http://www.doktori.hu (Magyar Felsőoktatási Akkreditációs Bizottság statisztikai adatai 2012-ig) 